\title{
Urban Development Process of Built Environments in Metropolitan Areas in Turkey: Case Study of Angora Settlement, Ankara
}

\author{
Münevver Özge Balta'; Ayşe Tekel ${ }^{2}$; and Halil İbrahim Tekel ${ }^{3}$
}

\begin{abstract}
The built environments of metropolitan areas are rapidly changing in response to urban development dynamics. The nature of the urban built environment continues to be influenced by the conflicting interests and expectations of various entities involved in the process of development planning and implementation. The formulation and implementation of urban development plans in Turkey is guided by the statutory provisions of the country's planning system. This process has led to piecemeal implementation through partial plans and plan amendments in metropolitan areas. This article attempts to determine how the private sector in metropoles in Turkey shaped the built environment in Turkey after 1980. Influence of neo-liberal policies and a partial planning approach set by a free-market economy instead of a comprehensive planning approach shaped urban space. As a capital, the urban development of Ankara has mostly been shaped by partial planning approaches and implementations and uncontrolled developments, especially on the southwest axis of the city's metropolitan area. For this reason, one of the largest settlement of southwest Ankara is the Angora Settlement, which has been selected as the case study. Examining the entities who play a part in the urban development process is important to control its consequences. In this article, the case of Angora Settlement is used to question the planning process and entities in the development of urban built environments, and studies this settlement to identify and question which entities determine the components of the built environment in the urban development process. In particular, this paper captures the dominance of the structural interests of the private sector in shaping Angora's land use pattern, which is important because it reveals the uncontrolled growth dynamics in developing countries. DOI: 10.1061/(ASCE)UP.1943-5444.0000101. (C) 2012 American Society of Civil Engineers.
\end{abstract}

CE Database subject headings: Urban development; Turkey; Case studies.

Author keywords: Urban built environments; Urban development process; Angora settlement; Entity; Partial plans.

\section{Introduction}

The shape of urban built environments are developed under the influence of entities who have different expectations and enjoy a variety of benefits. The development and transformation process of urban environments is determined by the interactions among these stakeholder interests. The demands of these entities, which are not defined within an organizational structure, cause one or more entities to come to the foreground and result in the shaping of the space according to their benefits. An approach of this kind necessitates planning shaped by the dominant entity.

One of the entities that shape space in developing countries is the private sector. The holes in planning legislation and the limited

\footnotetext{
${ }^{1}$ Research Assistant, Faculty of Engineering, Dept. of Geomatic Engineering, Aksaray Univ., 68000 Aksaray, Turkey; formerly, Research Assistant, Dept. of Urban and Regional Planning, Faculty of Architecture, Gazi Univ., 06570 Maltepe, Ankara, Turkey (corresponding author). E-mail: ozgebalta@aksaray.edu.tr

${ }^{2}$ Associate Professor, Faculty of Architecture, Dept. of Urban and Regional Planning, Gazi Univ., 06570 Maltepe, Ankara, Turkey. E-mail: atekel@gazi.edu.tr

${ }^{3}$ Faculty of Economics and Administrative Sciences, Bilkent Univ., 06800 Bilkent, Ankara, Turkey. E-mail: atekel@gazi.edu.tr

Note. This manuscript was submitted on July 22, 2010; approved on August 16, 2011; published online on February 15, 2012. Discussion period open until August 1, 2012; separate discussions must be submitted for individual papers. This paper is part of the Journal of Urban Planning and Development, Vol. 138, No. 1, March 1, 2012. CASCE, ISSN 0733-9488/ 2012/1-70-77/\$25.00.
}

capabilities of local authorities may result in the domination by the private sector in metropolitan growth areas. Because rent is one of the main motivations of the private sector, public benefit is disregarded and development of urban space becomes scattered and disconnected to the whole.

The formulation and implementation of urban development plans in Turkey are guided by the statutory provisions of the country's planning system. The process stimulates the development of entities' individual behavior, and individual acts come to the foreground primarily through piecemeal implementations as partial plans and plan amendments. Local governments frequently use partial plans for the purpose of steering the public benefit. In actuality, the urban space is broken into pieces and is privatized through these plans, and public spaces are turned over to the private sector through urban projects/partial plans. To allay reactions that the public may put forth, local governments define the plans in planning regulations and apply the procedures anticipated by the law predominantly in a stylistic manner, thereby rendering the applications different from the plan decisions. Partial plans may completely change the urban settlement character.

The private sector is a key determinant in the creation of the built landscape, especially in metropolitan growth areas. Since 1980, urban development in metropoles in Turkey has been primarily incremental rather than holistic. In the process, urban development planning has tended to be piecemeal, resulting in the fragmentation of the urban built environment. The urban development on the southwest axis of the Ankara metropolitan area has been shaped primarily by implementations of this kind. For this reason, Angora 
Settlement, which is located in Ankara's southwest corridor, has been selected as the case study area in the prepared evaluation.

The aim of this article is to examine the role of different entities in the current urban development planning and implementation practice in Turkey by studying Angora Settlement. Through the case study, this paper also analyzes the entities that created the components of urban built environments in new residental areas of metropolitan cities, created and how. The case study area, plans, plan decisions, and municipal council decisions used in the development process of urban built environments are scrutinized in detail.

This paper consists of four major parts: (1) a literature review on urban built environment and entities, (2) the development process of the urban bult environment in Turkey, (3) the urban development process of Angora Settlement, and (4) a conclusion in which the findings are discussed. The first part discusses urban built environments, components that make up urban built environments, entities participating in the design, and production processes of urban built environments on the basis of a survey of the literature. In the second part, the development process of urban built environments in Turkey, the entities participating in the process, and the tools used are analyzed in relation to planning regulations. In the third part, the development process of urban built environments and the entities participating in the process and their roles are examined, and the present planning system used is questioned through the Angora case. Finally, the findings are discussed in the conclusion.

\section{Methodology}

Literature on the urban built environment was reviewed to form a therotical background of the research. Previous studies on Ankara planning policies and the settlement were reviewed, and the settlement was consequently chosen as the research area. Partial planning processes, master plans, partial plans, plan amendments, plan decisions, and municipal council decisions of Angora for approval plans after 1980 were examined. Components of the urban built environment, entities, and tools were analyzed for the Angora Settlement. The findings characterize the political economy of the land use policy presented in the paper as derived from a case study of urban development planning and implementation in Turkey in general and in the Ankara metropolitan area in particular. Limitations of the study result from limitations in content from examination of the urban development process of built environments in metropolitan areas by planning practises in the Angora Settlement.

\section{Defining the Urban Built Environment and the Entities}

This chapter has two major parts. The first part is the definition and components of the urban built environment The second part addresses the entities in the development process of the urban built environment, as given in this section.

\section{Definition and Components of the Urban Built Environment}

The urban built environment is a whole that includes all human activities at the conjunction of "land use," "transportation systems," and "physical environment" (Handy et al. 2002). Carmona (1999) categorized components of the urban built environment under nine titles, as spatial, morphological, contextual, visual, perceptual, social, functional, sustainable, and design-planning processes (Carmona, 1999). Components of urban built environments are defined at three levels in Table 1. Components of settlement appear at the first level, components of plot appear at the second level, and components of building appear at the third and last level.
Table 1. Components of Urban Built Environments (Adapted from Hall and Doe 2000)

\begin{tabular}{|c|c|c|}
\hline $\begin{array}{l}\text { Level } 1 \\
\text { urban scale }\end{array}$ & $\begin{array}{l}\text { Level } 2 \text { plot } \\
\text { scale }\end{array}$ & $\begin{array}{c}\text { Level } 3 \text { building } \\
\text { scale }\end{array}$ \\
\hline $\begin{array}{l}\text { - Greenfield } \\
\text { development }\end{array}$ & - Garage blocks & $\begin{array}{l}\text { - Extensions to } \\
\text { buildings }\end{array}$ \\
\hline $\begin{array}{c}\text { - } \text { Comprehensive } \\
\text { redevelopment }\end{array}$ & - Parking areas & $\begin{array}{l}\text { - Structural design } \\
\text { characteristics }\end{array}$ \\
\hline - Road network & $\begin{array}{l}\text { - Amenity spaces/play } \\
\text { areas }\end{array}$ & - Crossovers \\
\hline - Open area & - Garden sizes & $\begin{array}{l}\text { - Private parking } \\
\text { lots/hardstandings } \\
\text { and forecourts }\end{array}$ \\
\hline - Density & $\begin{array}{l}\text { - Conversions of } \\
\text { buildings to flats } \\
\text { - Nonresidential areas } \\
\text { - Pedestrian network and } \\
\text { footways } \\
\text { - Traffic flow } \\
\text { - Plot amalgamation } \\
\text { - Backland development } \\
\text { - Plot separation and } \\
\text { density } \\
\text { - Infill development }\end{array}$ & - Building quality \\
\hline
\end{tabular}

Level one constitutes the basic components of the change occurring in the urban built environment and of the backbone of the settlement. Level two constitutes components such as parking areas, pedestrian network, and traffic flow. Level 3 includes special arrangements at the building scale.

Urban built environments provide insights into the whole of human behavior and symbolize political, social, and cultural elements. Urban built environments also reflect the spirit of their period. Therefore, cities can be read as a text that narrates the story of multilayered signs and symbols. When cities are considered as texts, urban built environments function as biographies of urban changes (Knox and Ozolins 2007).

Changes are significant for comprehending urban built environments (Habraken 1998). That the changing social structure is reflected onto the urban built environment is inevitable. Changes in the urban built environment give clues about the structure of the society. In this respect, the urban built environment reflects the relations, actions, and contradictions in society as well.

Whereas changes in the urban built environment may negatively affect the character of the place and cause its deterioration, they may also strengthen its. Spatial changes realized on a social sensitivity basis reinforce the identity of the space in which change takes place (Hall and Doe 2000). As such, when changes in the urban built environment reach a quantitative accumulation, they pave the way for a qualitative transformation (Ünlü 2006).

\section{Entities in the Development Process of Urban Built Environment}

At this point, how individuals or entities interpret the present planning system and regulations, and how they reflect them onto the space are significant. In other words, at its implementation stage, a newly developed planning theory is reshaped by the individuals of that society and the entities effective in the planning, and it is reflected onto the space in this form. Who are these entities? 
Knox and Ozolins (2007) categorize the entities appearing in the design and production process of the urban built environment in eight groups. These are:

- Land owners,

- Speculators,

- Entrepreneurs,

- Builders,

- Consumers,

- Real estate firms, financiers, and other professionals,

- Government and regulatory agencies,

- Market Trends (Knox and Ozolins 2007).

According to Logan and Molotch (1987), the activity of the entrepreneurs is of primary importance in the shaping of the urban system. The demands of these entities that are not defined within an organizational structure cause one or more entities to come to the foreground and result in the shaping of the space according to their benefits. This is because the planning approach developed at this point is not actually planning; it is in the form of a monolithic intervention that would increase the benefits of that entity (Cox and Mair 1989).

Local planning authorities are assumed to consider the wider public and political interest, but they are usually under pressure of builders and central government (Carmona 1999).

Entrepreneurs, builders, and professionals are expected to act with reference to planning obligations whereas local authorities control the implementation process according to planning decisions. Depending on control approaches, the public can also take place in planning the implementation process (Ünlü 2005).

The leading role of the entrepreneurs in the urban development process affects the decisions relating to the form and structure of the land development process. Choosing land and project scope is the first role the entrepreneurs should fulfill. Most entrepreneurs serve to obtain the land, design, construction, and marketing. Especially with the increase in urban extension in large cities, the significance of obtaining land has increased for entrepreneurs. Today, largescale entrepreneurs especially prefer buying land with speculative value on city peripheries before even deciding on the project to be realized on this land.

Central and local governments play a determining role in the formation of urban built environments, and local governments legalize urban built environments through development rights and invest in them.

Habraken (1998) defines the urban built environment as a complicated game played by many entities over a long period. The aim of this game is not that one side wins and controls the other, but that all people are allowed to exist in peace and welfare. To gain an insight into the game, knowing which entity demonstrates which action is necessary, and to play, knowing the characteristics of the entities is necessary. Even though entities compete over the components of the these environment, these environments continue to exist in a common unity. Therefore, reaching a legal reconcilement forms the basis of the game (Habraken 1998).

Goodall argues that urban growth dynamics cause urban built environments of metropoles to undergo rapid development. Urban growth and structure are fundamentally affected by changes in the economic base of urban area (Goodall 1972).

Ural noted that sustainable urban developments depend on several key issues, and one of the most important issues is policy (Ural 2010). The policy issues that lead to the necessary legislations are the guides for correct planning. Global pressure exists to demand dominant responsibility of the professionals involved in the process of urban planning. Ural pointed out that the awareness of this responsibility demands the consideration of a technical attitude to have a multidisciplinary approach to all related work
(Ural 2010). One of the critical entities who has responsibility for sustainable development and urban planning process is the local government. Cuthill and Fien (2005) suggested that collaborative action can be achieved in terms of improved capacity regarding local sustainability issues on the basis of the local government's responsibility to facilitate community participation within the capacity building process (Özçevik et al. 2010).

These entities may interact with one an other in both competitive and cooperative ways. Each entity may have very simple decision criteria and desires, but the dynamic folding of the system can give rise to complex patterns and flows (Allen 1997). In this manner, individual actions begin to produce their own pattern of urbanism in the urban built environment.

\section{The Development Process of the Urban Built Environment In Turkey}

As in many countries with a planning system at the national level, the Turkish system depends on a hierarchy of development plans to direct and control the production of the urban built environment. Their structure and content are defined in planning legislation, which is the main bundle of rules that directs all planning and construction facilities in the urban built environment. Urban development plans in the Turkish planning system are detailed end-state blueprint plans, which envision that a time would come and the spatial development of any city would be completed in the specific planning period. The allegation of the planning system is to control every detail during urban development. The planning process can be classified by plan preparation and plan implementation process. Plan preparation and plan implementation processes are not separated from one an other in the interactive process, which conceives each process within a procedural context as working dependent on one an other. The plan preparation process refers to creation of a medium for operation of decision-making mechanisms in which entities' different motives come up against one an other and the plan-making process represents acquiring development plans as end product. In contrast, the plan implementation process refers to controlling both production of urban plots and construction of buildings in accordance with planning decisions. Development plans, of which structure and content are defined in planning legislation, are the main planning control tools in the Turkish system. Urban Development Law (3194), issued in 1985, exists at the very center of this legislation and is the main law directly related to production of the urban built environment (Ünlü 2005).

Planning regulations provide a legal framework for directing and monitoring the structuring activities, and determine the course of action of the entities who take part in the process and the procedures, relating to the process. In the development of the urban built environment in Turkey, input relating to the settlement is determined by master plans, input relating to land morphology by implementation plans, and detailed input by layout plans and architectural projects.

According to Article 5 of the Urban Development Law (numbered 3194) of Turkey, an urban master plan is a detailed report indicating the general and regional land uses and the future population distribution patterns. The master plans provide development objectives and optimum sizes of various urban centers with supporting maps and layouts on infrastructure provision.

Master plans are implemented on the approval of the municipal council within the borders of the municipality and neighboring areas. However, outside these borders, plans prepared by the governorship or under its jurisdiction are implemented by approval of the governorship (provincial council). Implementation plans 
designed for areas within the borders of the municipality or neighboring areas are prepared by the related municipalities and are implemented after being voted on by the municipal council. Plans for areas outside these borders are prepared by the governorship or under its jurisdiction, and implemented after being voted on in the provincial council (Ünal 2003). In metropolitan cities, master plans are prepared by metropolitan municipalities, and implementation plans by county municipalities, and are then approved.

An implementation plan indicates structural plots of various regions, their density and organization, the application stages, and other details relating to development application programs necessary for roads and applications demonstrated on present approved maps in accordance with cadastral standing, if any, and drawn in line with master plan principles.

Within the municipality borders, planners or architects present a proposal concerning the urban built environment or a change considered for implementation in the present urban built environment to the related municipality, and it is evaluated by professionals working in the municipality and debated in the municipal council. The proposal accepted after the evaluation is then posted for 30 days and submitted to a review by the public. Objections made during the posting period are considered within 15 days, and the proposal is either accepted or refused as a result of this entire process. The process is operated as a technical one, and the entities involved can act independently of one another. The operation of the process stimulates the development of the entities' individual behavior, and individual acts mostly come to the foreground through partial plans and plan amendments.

'The Regulations Concerning Principles of Plan Preparation, formed in relation to Urban Development Law numbered 3194, define partial plans. A partial plan is prepared in case the present plans fall short in addressing the settled population or when related managements decide that new settlement areas should be opened to use and their borders should be defined. The partial plan supplies the social and technical infrastructure needs that are not integrated into the plan and are not included within the borders of any type of current plan of any scale, the construction of which is possible in line with the plan preparation principles of this regulation. A partial plan is provided in its entirety along with its report.

Partial plans are prepared and approved within the borders of the municipality and neighboring areas, by the municipalities. Partial plans may have the overall effect of changing the character of a location, thereby resulting in the changing of the settlement pattern. The effects caused by this change can only be felt over a long period. Plot-based approaches in rapidly expanding metropolitan areas are also triggered by the increasing demands of private entrepreneurs.

After the legal arrangements made in the first half of the 1980s, the central government's role in planning has diminished, and authority has been transferred to the local government. However, the limited experience and capacity of local governments resulted in urban space to be developed through the private sector, especially in metropolitan areas. Particularly during these years, urban fringe faced partial developments for middle-high and high income groups. The holes in planning legislation and the popularity of partial plans resulted in a scattered development in metropolitan areas. Big capital groups directed urban land use in line with their wills in areas right next to municipal boundaries.

As healthy urbanization policies could not be realized in Turkey, after the 1960 s the population densified in certain big cities. Ankara has been one of the three fastest growing cities. The rapid growth in these cities resulted in infrastructure, environment, and housing problems. Ankara has developed through partial plans after the 1980s. The private sector realized many mass housing projects in the eastern and western parts of Ankara depending on the partial plan concept of the Urban Development Law (3194).

In contrast, density increments and land use changes from public uses to housing and commerce have been realized through plan modifications. In 2004, metropolitan municipality boundaries were enlarged and the 2023 comprehensive plan has been prepared to control the development of the city and resist partial developments. This reduced the popularity of partial plans. During this process, Angora housing has been a typical development example of a partial approach.

\section{Angora Settlement Development Process}

\section{Angora Settlement, Its Location and Structure}

As the administrative center and the capital, in which decisions on solution to problems are made, Ankara is also a city in which problems are confronted that, arise from executive authorities' not applying these decisions.

After becoming the capital and until 1969, Ankara was twice planned in accordance with the city master plan approach, although it demonstrated a development inconsistent with plan decisions. The fact that both plans were limited by municipality borders initiated, on the one hand, demands for concentration within development borders and, on the other hand, tendencies toward illegal and comparatively independent structuring outside the borders of the development plans. The factors that prevented both plans from being successful include development warrants used without initiative, a variety of methods devised by pressure groups desiring structuring beyond construction, and land speculation. For the purpose of preparing the Ankara City Master Plan, the Ankara Metropolitan Area Bureau for the Master Plan was established under the local government in 1969, and the Bureau started to make plan decisions relating to the entire metropolitan area of Ankara. The city's macroform was determined in 1972, yet the bureau avoided attaining an inflexible solid master plan, supported the sustainability of the planning, and adopted the principle of reaching a conclusion by choosing from alternative solutions (A. Tekel, "Metropolitan planning and planning administration in Turkey: Experience of Ankara between 1969-1984," unpublished doctoral dissertion, 2000).

Whereas work on metropolitan planning continued, the duration of preparing the plan was used as an excuse to bring to the foreground partial plans actualized for the aim of satisfying so-called local needs. However, such planning approaches that do not head toward a shared goal caused deviations from the fundamental principles of planning. Although serving mostly the interests of pressure groups, fragmented planning approaches also damaged the public interest, thereby hampering the implementation of planning decisions to their fullest. The Ankara Metropolitan Area Master Plan was approved in 1982. Demands for local plans rapidly increased after this year. The Ankara Metropolitan Municipality was founded in 1984, and the authority to plan and certify city plans for the Ankara metropolitan area invested in the municipality. Nevertheless, until 2006 Ankara continued its development in line with fragmented planning approaches without an approved plan. On the basis of not achieving an approved plan within Ankara's metropolitan area borders until 2006 lies the idea that development was steered using partial plans.

In the Ankara Metropolitan Area Master Plan approved in 1982, the urban development of Ankara was directed toward the west. Nonetheless, development in the western corridor was shaped independent of plan decisions and mostly by market mechanisms through partial plans (Aras and Eke 2009). Devoid of a comprehensive master plan, Ankara was decentralized through individually 
prepared and approved partial plans and local plans forming an uneven mosaic rather than a well-coordinated urban fabric (Aras 2008).

During these years, the city continued its development in the west and southwest direction through the implementation of mass housing applications south of the Eskişehir Road for, ayyoluUmitkoy projects. Cooperatives and large-scale construction companies began to share in the unearned income appearing in development areas by producing mass housing as a result of an increase in government funds and other financial sources (Akın, "Urban growth and urban rent: a case of Ankara," unpublished doctoral thesis, 2007).

Among the mass housing formed in this fashion, Angora Settlement was selected as the case study because of its huge project area and its formation on the basis of cooperative and company initiatives, and its formation process has been regarded as worth analyzing. Angora Settlement is located in the southwest corridor of Ankara city and has a planning area of 203.29 ha.

The area borders the Hacettepe University Campus Zone in the west, Ankara Metropolitan Municipality and Neighboring Areas Zone in the south, a partial plan zone approved by the Ministry of Works and Housing in the northwest, and Beykent and Planlamacilar (SPA) Housing Construction Cooperative zones in the northeast. There are 1,929 residences within the mass housing area, 945 of which are detached (villas) and 984 of which are point blocs (12-13 story buildings) and row houses (6-8 storys) (Konut-18 Housing Cooperative Landscape Planning 2010).

\section{Angora Settlement Planning Process}

The development process of the urban built environment at Angora Settlement started in 1989. In 1989, a housing construction cooperative that included politicians and bureaucrats was founded and named Cooperative 18. The Akara Metropolitan Municipality supplied the Cooperative 18 housing construction cooperative with land of 21.6 ha belonging to the Land Office between Bilkent and Umitkoy. The cooperative bought this land on December 8, 1992.

However, the 21.6 ha of land belonging to the Land Office later became insufficient for the cooperative. Members of the cooperative conveyed the situation to the metropolitan municipality, decided to expropriate the areas neighboring the present area. The cooperative and the municipality signed a protocol under which, the municipality declared this neighboring area a mass housing zone and would turn it over to the cooperative after completing the expropriation procedures and the infrastructure. During the process, the metropolitan municipality realized the expropriation procedure necessary for the public interest and for the prosecution of public services to provide a cooperative with land.

Subsequently, an area of 600 ha including the area in question was declared the Beytepe mass housing zone by the Governorship of Ankara at the request of the Ankara Metropolitan Municipality presidency. The Cooperative 18 housing construction cooperative was also alloted 200 ha of land to the south and southeast of the Beytepe mass housing zone. The entities participating in the development process of the urban built environment at Angora Settlement and their roles are described in Table 2.

In the formation of the decisions concerning the settlement, land morphology, and structure that make up the components of the urban built environment at Angora Settlement, Urban Development Law numbered 3194 and the principles and plans determined by the Metropolitan Municipality Law, numbered 5216, were utilized as tools (Table 3).

Decisions concerning settlement are determined by the partial plan of 1/5,000 scale (Fig. 1); decisions concerning land morphology are determined by the implementation plan of $1 / 1,000$ scale
Table 2. Entities Participating in Development Process of Urban Built Environment at Angora Settlement and their Roles

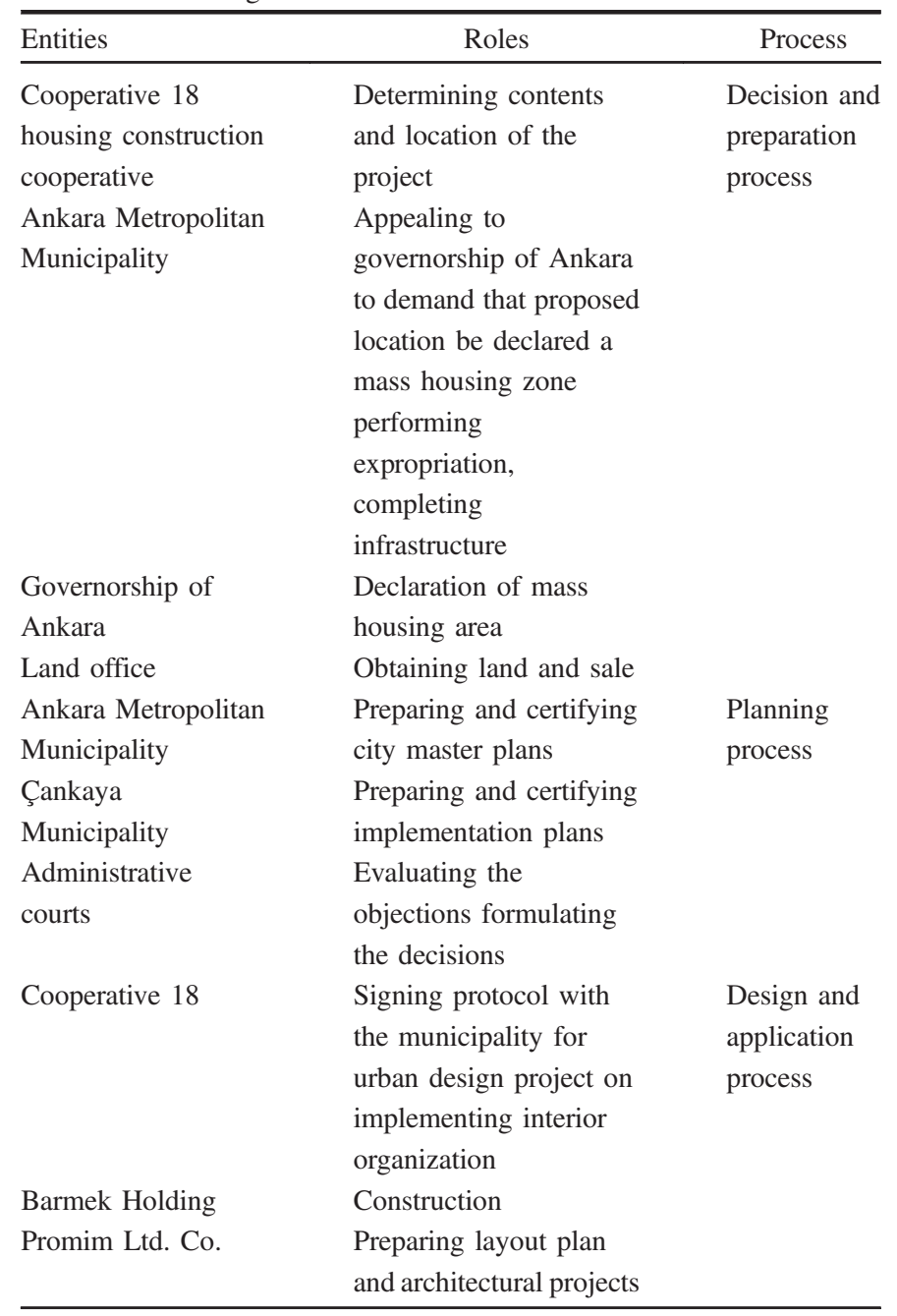

and the layout plan, and decisions concerning the construction scale are determined by architectural projects. The partial plan prepared for the Beytepe mass housing zone identifies, the residential location, commercial areas, green areas, and social facility areas and their concentration, indicating that, in social, cultural, and recreational areas, outdoor indoor swimming pools, tennis courts, mini golf courts, restaurants, cafes, club buildings, and the like could exist.

The partial plan prepared for the Beytepe mass housing zone came into effect with the decision of the Ankara Metropolitan Municipal council in January 1990, and the implementation plans came into effect with the decision of the same office in February 1990 (Ankara Metropolitan Municipality 1990).

However, subsequent changes, were made in these plans three times in accordance with the requests of the Cooperative 18 housing construction cooperative. In the first two set of changes, construction precedents were increased. This change was approved by the Metropolitan Municipal Council in July 1994. The last set of changes to the plan proposed a local trade center in the place of green areas, and a sociocultural, commercial center, and recreational facilities in the place of sports facilities, parks and children's playgrounds.

The duty of preparing and certifying implementation plans at Angora Settlement belongs to the Çankaya Municipality. Nonetheless, in the process, Ankara Metropolitan Municipality prepared 
Table 3. Components of Urban Built Environment at Angora Settlement, Entities and Tools

\begin{tabular}{|c|c|c|c|}
\hline & Settlement (level 1) city/city fragment scale & Land morphology (level 2) plot scale & Detail (level 3) construction scale \\
\hline Quality & $\begin{array}{l}\text { Structuring order concentration decisions, } \\
\text { transportation networks, number of } \\
\text { residences }\end{array}$ & Plot designs & Detailed designs, building designs \\
\hline \multirow[t]{4}{*}{ Entities } & Governorship of Ankara & Ankara Metropolitan Municipality & Çankaya Municipality \\
\hline & Land office headquarters & Çankaya municipality & Barmek Holding \\
\hline & Ninth administrative court of Ankara & $\begin{array}{l}\text { Cooperative } 18 \text { housing construction } \\
\text { cooperative }\end{array}$ & Promim Ltd. Co. \\
\hline & $\begin{array}{l}\text { Ankara Metropolitan Municipality } \\
\text { Cooperative } 18 \text { housing construction } \\
\text { cooperative }\end{array}$ & Promim Ltd. Co. & $\begin{array}{l}\text { Cooperative } 18 \text { housing construction } \\
\text { cooperative }\end{array}$ \\
\hline Tools & $\begin{array}{l}\text { Plans: } 1990 \text { Ankara metropolitan area master } \\
\text { plan of } 1 / 50,000 \text { scale, Beytepe mass } \\
\text { housing zone master plan of } 1 / 5,000 \text { scale. } \\
\text { Laws: The expropriation law, numbered } \\
\text { 2942. The land office law, numbered } 1164 \text {, } \\
\text { and its application legislation the urban } \\
\text { development law, numbered } 3194 . \text { The } \\
\text { metropolitan municipality law, numbered } \\
\text { 3030/5216 }\end{array}$ & $\begin{array}{l}\text { Plans: Beytepe mass housing zone } \\
\text { implementation plan of } 1 / 1,000 \text { scale, } \\
\text { 1/500 layout plan. } \\
\text { Laws: The urban development law, } \\
\text { numbered } 3194 \text {. The metropolitan } \\
\text { municipality law, numbered } 3030 / \\
5216 .\end{array}$ & $\begin{array}{l}\text { Plans: Beytepe mass housing zone } \\
\text { implementation plan of } 1 / 1,000 \text { scale, } 1 / 500 \\
\text { layout plan architectural project. } \\
\text { Laws: The urban development law, numbered } \\
\text { 3194. The metropolitan municipality law, } \\
\text { numbered 3030/5216. }\end{array}$ \\
\hline
\end{tabular}

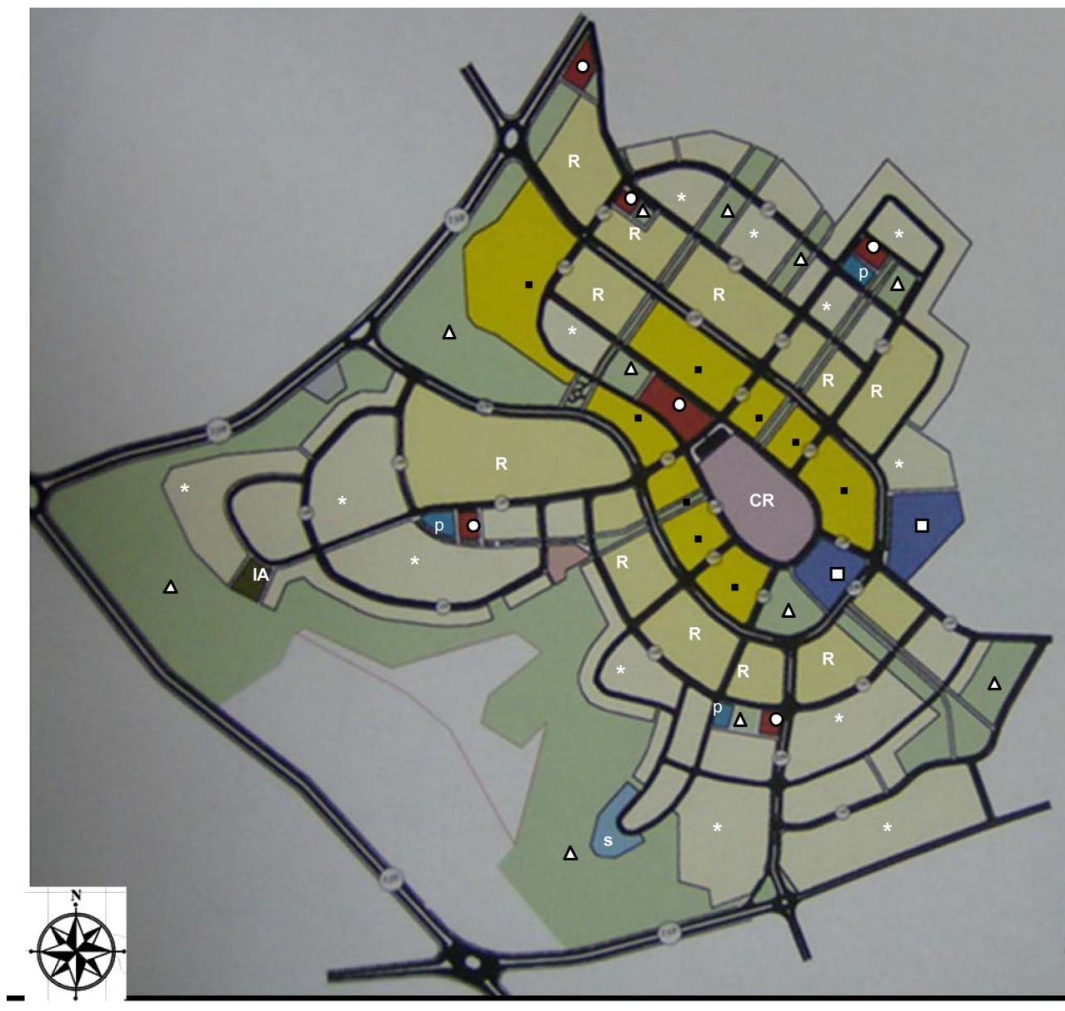

\begin{tabular}{|c|c|}
\hline \multicolumn{2}{|c|}{ Legend } \\
\hline$\Delta$ & Recreational areas \\
\hline 0 & Commercial areas \\
\hline * & Villas \\
\hline $\mathbf{R}$ & Row houses \\
\hline$\cdot$ & Point blocks \\
\hline CR & $\begin{array}{l}\text { Commercial-recreational } \\
\text { areas }\end{array}$ \\
\hline$\square$ & Primary school \\
\hline$p$ & Pre-school \\
\hline IA & Instituonal areas \\
\hline s & Socio-cultural areas \\
\hline
\end{tabular}

Fig. 1. Beytepe mass housing area master plan

and approved the development plan on which Çankaya Municipality filed a court case against Ankara Metropolitan Municipality at the 9th Administrative Court of Ankara. As a result of the court case, the implementation plans prepared and approved by the Ankara Metropolitan Municipality were annuled by the 9th Administrative Court of Ankara.

In the meantime, members of the Cooperative 18 housing construction cooperative partially took into consideration the local construction plan (partial plan) and implementation plan principles, and had Promim Ltd. Co. prepare the area's layout plan and architectural projects, and the planned projects were implemented by Barmek Holding.

There upon, the Çankaya Municipality Commission ruled that the buildings realized against the implementation plan and the licenses obtained should be demolished according to the $32 \mathrm{nd}$ and 42nd articles of the Urban Development Law, and that the 
related parties be fined. The on-site analyses of buildings that had reached the settlement stage, conducted by the Çankaya Municipality Building Audit Units, detected that almost all of the buildings had been constructed counter to the licenses and that, under these circumstances, composing settlement licenses according to master and implementation plans and plan notes was impossible. Moreover, demolishing the buildings counter to the licenses was impossible, as all were completed and inhabited.

On the basis of this finding, and again in line with the requests of the members of the Cooperative 18 housing construction cooperative, a change of plan notes was applied to the partial plan of $1 / 5,000$ scale and in the implementation plans of $1 / 1,000$ scale in line with the layout plan and architectural projects prepared by Promim Ltd. Co. As such, arrangements at the construction scale were performed indepent of plan decisions.

Given this change, structuring order would be determined in the 1/500 scale layout plan; the cooperative would organize parks, playgrounds, shared green areas, and roads outside the housing plot residential area; in the multistorey housing plots $10 \mathrm{~m}^{2}$ of park and playground area would be alloted for each residence; lofts could be utilized outside the construction precedent account and under the condition that independent units would not be formed in the housing plots; no limitations on roof style and inclination would be imposed; and separations using plants, wire, fences and, for which difference in rise exists, structural brick walls for the purpose of reliance could be made to the indicate the areas of utilization according to the portion of shares among residences, under the condition that it does not become private property.

The plan notes also indicated that parking lot needs should be met within the housing plots, at least three parking lots should be constructed for each residence in two-storey buildings, garage inclinations should make parking a second car possible, stairs, platforms, and the like could be constructed for building entrances outside the building approach range, buildings could receive service from the roads arranged within plots, buildings' entrance elevation would be determined by the layout plan of 1/500 scale, and buildings would mostly receive elevation from the natural ground $(0.00$ elevation) and basement elevation would be $\pm 1.50 \mathrm{~m}$.

Evaluation of the development process of the urban built environment at Angora Settlement showed that the process defined in the planning legislation is operated merely modally. The partial plan used in the process is brought to the foreground, supposedly to meet the local public's housing demand. Yet, the actual purpose has been determined as legally initating the construction process in the area, the content and location of which was selected by the Cooperative 18 housing construction cooperative. The partial plan and implementation plans utilized in the development process of the urban built environment were altered at the application stage according to the demands of the Cooperative 18 housing construction cooperative, and this change was legalized through changes in the plan notes, approved by Ankara Metropolitan Municipality and Çankaya Municipality.

\section{Conclusion}

Urban built environments, consisting of components at the settlement, plot, and construction levels, are formed as a result of the demands, purposes, resources, and interrelations of different entities with different interests. The demands of these entities, which are not defined within an organizational structure, cause one or more entities to come to the foreground at certain times and result in the shaping of the space according to their benefits. Leaving the formation process of the urban built environment up to market mechanisms results in the shaping of such environments mostly in the direction of pressure groups' demands. Comprehending the urban built environment necessitates understanding these entities and their demands, purposes, and interactions.

In the Turkish planning system, local governments are responsible, in the development of the urban built environment, for coordinating among the entities and ensuring that the planning is focused on the public interest. Yet, in practice, from time to time local governments use the planning system to conceal the forcefulness of capital owners in the creation of space. In this process, partial plans are brought to the foreground, supposedly to meet local needs and, as such, the public's comprehension of need is answered. The planning system is operated modally, thereby alleviating potential public reactions. In this process, public land is privatized, and public domain and forest areas are turned over to the private sector. However, the liberalization trends coupled with the decentralization demands of the age, which also affected Turkey, caused the abolishment of these planning units. This left ground to local authorities that could not easily with stand the pressures of private sector forces; eventually, urban built environments ignored public benefits.

The paper underlines the skewed involvement of private sector interests pervading Angora's land management practices to the detriment of a shared development vision for Ankara. In the Angora Settlement example, the Ankara Metropolitan Municipality declared an area of 600 ha, including the Angora Settlement, as mass housing zone to meet the so-called needs of the local public. Thus, the privatization of public land and turning over public domain and forest areas to the private sector through urban projects were veiled. Although the planning legislation was expected to direct and determine in the development process of the urban built environment at Angora Settlement, the process was realized in a completely different manner. First, Ankara Metropolitan Municipality prepared and approved the partial plan, which defines the construction legislation and determines decisions relating to the settlement pattern of the urban built environment. Using this plan, changes were made three times, in line with the requests of the Cooperative 18 housing construction cooperative. Afterward, Ankara Metropolitan Municipality instead prepared and approved the implementation plans of Çankaya Municipality although the plans were not within its jurisdiction. In the meantime, by partially following the development plan decisions, the Cooperative 18 housing construction cooperative prepared and implemented the layout plan, in which decisions concerning the land morphology of the urban built environment are made, and the architectural projects, in which decisions at the building scale made. Processes not operating in line with the planning legislation were legalized through revisions in the partial plans and implementation plans. In short, Ankara Metropolitan Municipality operated the process defined in the planning legislation only modally and applications were implemented independent of plan decisions. Thus, the unearned income transfer turned over to the private sector through urban projects was also masked.

Yet, the planning and design process in the development of any given urban built environment should necessitate that all involved entities behave in coordination, that all development decisions and legal arrangements are followed, and that public interest is given priority in the proposed project. For this reason, policies that affect developments in the city should be obtained within an organizational network or reconciliation environment with relations only in that society. After establishing reconciliation among the entities, the local and central governments that possess the power of planning should function like coordinators and direct the planning toward the public benefit. 
This phenomenon is as detrimental to urban form as having no plans at all because in both cases speculative private sector forces win the day rather than the community. In some cases, the urban rent created and speculatively used around new settlements, such as Angora, which was undertaken to study the urban development process.

Consequently, partial plans have resulted in uncontrolled development of metropoles. Such development increases infrastructure costs and burdens local authorities. The scattered and collage type of development creates problems, such as incongruity of functions, environmental problems, and higher of public services costs. To overcome such problems, the uncontrolled growth should be stopped and development policies that address both public and private sectors should be addressed.

The following concluding remarks from this study may contribute to the planning literature:

- Analyzing planning policies and implementations of built environments in metropolitan areas,

- Bringing out the peculiarities in the urban development process in developing countries, as a result of their planning procedures and practices,

- Investigating one of the largest settlements in southwest Ankara using empirical data,

- Questioning the entities that the components of the built environment determine in the urban development process.

\section{Acknowledgments}

The authors gratefully acknowledge the constuctive comments of the editor and reviewers attributable to their contribution to the paper, which helped to improve the quality of the paper.

\section{References}

Allen, P. M. (1997). "Cities and regions as self-organising systems: Models of complexity." Gordon and Breach, The Netherlands.

Ankara Metropolitan Municipality. (1990). "Report on the Beytepe mass housing zone development plan of 1/5000 scale and 1/1000 scale." Ankara, Turkey.

Aras, M.Sc. thesis, Institute of Natural and Applied Sciences, Gazi Univ., Ankara, Turkey (in Turkish).
Aras, M. Ö, and Eke, F. (2009). "Parçayı Planlamak-Planlamayı Parçalamak." 33. World Day of City Planning, Colloqium, Antalya, Turkey, 1-14, (in Turkish).

Carmona, M. (1999). "Residental design policy and guidance: content, analytical basis, prescription and regional emphasis." Plann. Pract. Res., 14(1), 17-38.

Cox, K. R., and Mair, A. (1989). "Urban growth machines and the politics of local economic development." Int. J. Urban Reg. Res., 13(1), $137-146$.

Cuthill, M., and Fien, J. (2005). "Capacity building: Facilitating citizen participation in local governance." Aust. J. Publ. Admin., 64(4), 63-80.

Goodall, B. (1972). The economics of urban areas.. Pergamon Press, Oxford, NY.

Habraken, N. J. (1998). The structure of the ordinary: Form and control in the built environment. J. Teicher, ed., M.I.T. Press, Cambridge and London, 6-7.

Hall, T., and Doe, J. (2000). "Design control policies for small areas: The dacorum residental area character study." Plann. Theory Pract., 1(2), 235-256.

Handy, S. L., Marlon, B., Reid, E., and Richard, K. (2002). "How the built environment affects physical activity: Views from urban planning." Am. J. Prev. Med., 23(2S), 64-73.

Knox, P., and Ozolins, P. (2007). "The built environment.” Urban design reader, M. Carmona and S. Tiesdell, eds. Architectural Press, New York, 313-318.

Konut-18 Housing Cooperative Landscape Planning. (2010). "Betype mass housing area 2200 housing units and social establishments." 〈http://www.promimproje.com/projects/projeler/konutalan/landscape _konut.htm $\rangle$ (Dec. 8, 2010).

Logan, J. R., and Molotch, H. (1987). Urban fortunes: The political economy of place, University of California Press, Berkeley, CA.

Ozcevik, O., Beygo, C., and Akçakaya, I. (2010). "Building capacity through collaborative local action: Case of Matra REGIMA within Zeytinburnu regeneration scheme." J. Urban Plann. Dev., 136(2), $169-175$.

Ural, O. (2010). "Best practices on land management strategies." J. Urban Plann. Dev., 136(2), 115-175.

Ünal, Y. (2003). Türk şehir planlama hukuku. Yetkin Yayınları, Ankara (in Turkish).

Ünlü, T. (2005). "Plan modifications within the contexts of planning control mechanisms Mersin case." Ph.D. thesis, Dept. of City and Regional Planning, The Graduate School of Natural and Applied Sciences of Middle East Technical Univ., Ankara, Turkey.

Ünlü, T. (2006). "Kentsel mekanda değişimin yönetilmesi.” METU JFA, 23(2), 63-92 (in Turkish). 